Verschuyl, J., J. L. Stephens, A. J. Kroll, K. E. Halstead, and D. Rock. 2021. Black-backed Woodpecker occupancy is extensive in green conifer forests of the southern Cascade Mountains, Oregon. Avian Conservation and Ecology 16(1):4. https://doi.org/10.5751/ACE-01725-160104 Copyright (C) 2021 by the author(s). Published here under license by the Resilience Alliance.

Research Paper

\title{
Black-backed Woodpecker occupancy is extensive in green conifer forests of the southern Cascade Mountains, Oregon
}

\author{
Jake Verschuyl ${ }^{1}$, Jaime L. Stephens ${ }^{2}$, Andrew J. Kroll ${ }^{3}$, Katherine E. Halstead ${ }^{2}$ and Dennis Rock ${ }^{4}$ \\ ${ }^{1}$ National Council for Air and Stream Improvement, ${ }^{2}$ Klamath Bird Observatory, ${ }^{3}$ Weyerhaeuser, ${ }^{4}$ Wildlife Investigations
}

\begin{abstract}
Black-backed Woodpeckers (Picoides arcticus) are widely considered a burned forest specialist across much of their range. Several recent studies have examined their occurrence in "green" coniferous forests that have not been recently burned, but Blackbacked Woodpecker occupancy and factors influencing occupancy in these forest types remain largely unexamined. We worked on the east slope of the southern Oregon Cascade Mountains and used playback call surveys with repeated visits to 90 transects in 2014 and 2015 to estimate occupancy probabilities by forest type while controlling for detection probability. We detected Black-backed Woodpeckers on $86 \%$ of survey transects in green forests composed primarily of mixed conifer, lodgepole pine (Pinus contorta), or ponderosa pine (P. ponderosa). We examined associations between occupancy probability and structural covariates in unburned forests, and found that occupancy did not vary with annual precipitation, large snag density, or snag basal area. Modeled mean occupancy across all transects was 0.87 (95\% CI: 0.78-0.93). Detection probability varied during each survey season, with transect-level detection probability reaching a maximum of $0.79(95 \% \mathrm{CI}$ : $0.70-0.85)$ in mid-June. Given high occupancy of green forests by Black-backed Woodpecker in our study area, we suggest that additional study of vital rates in green forests is critical for supporting conservation and management decisions for this species.
\end{abstract}

\section{Occurrence importante du Pic à dos noir dans les forêts de conifères verts du sud des montagnes Cascade, Oregon}

RÉSUMÉ. Le Pic à dos noir (Picoides arcticus) est reconnu comme un spécialiste des forêts brûlées dans une grande partie de son aire de répartition. Plusieurs études récentes ont examiné la présence de cette espèce dans des forêts de conifères « verts » (c.-à-d. qui n'ont pas brûlés récemment), mais son occurrence et les facteurs qui l'influencent dans ce type de forêts restent largement inexplorés. Nous avons travaillé sur le versant est des montagnes Cascade du sud de l'Oregon et avons utilisé des enregistrements et fait des visites répétées sur 90 transects en 2014 et 2015 pour estimer la probabilité d'occurrence par type de forêt, tout en ajustant pour la probabilité de détection. Nous avons détecté des Pics à dos noir sur $86 \%$ des transects dans des forêts vertes composées principalement de conifères mixtes, de pins tordus (Pinus contorta) ou de pins ponderosa (P. ponderosa). Nous avons examiné les liens entre la probabilité d'occurrence et les covariables structurelles dans les forêts non brûlées, et avons constaté que l'occurrence ne variait pas en fonction des précipitations annuelles, de la densité de gros chicots ou de la superficie basale de chicots. L'occurrence moyenne modélisée sur l'ensemble des transects était de 0,87 (IC $95 \%: 0,78-0,93$ ). La probabilité de détection a varié au cours de chaque saison de relevé, atteignant un maximum de 0,79 (IC $95 \%$ : 0,70-0,85) à la mi-juin à l'échelle du transect. Étant donné la forte présence du Pic à dos noir dans les forêts vertes de notre aire d'étude, nous pensons que des études sur les taux vitaux dans les forêts vertes devraient être effectuées pour éclairer la prise de décision touchant la conservation et la gestion de cette espèce.

Key Words: Black-backed Woodpecker; fire; green forest; occupancy; Oregon Cascades; Picoides articus; playback calls

\section{INTRODUCTION}

Woodpeckers (family Picidae) are often considered keystone species because they produce cavities in hard live and dead trees that are subsequently used by many other secondary cavitynesting species (Aubrey and Raley 2002, Remm and Lõhmus 2011). Woodpecker species are often used to guide forest management decisions due to their link to overall bird community health (Mikusinski et al. 2001, Drever et al. 2008) and to the disproportionate influence they have on the communities in which they occur (Martin et al. 2004, Virkkala 2006). Due to their common use of recently burned forests in western North America, Black-backed Woodpeckers (Picoides arcticus) are often used to support the maintenance of high-intensity fires instead of (or in addition to) fire-surrogate management treatments within fireprone landscapes (Hanson and North 2008, Hutto 2008, Cahall and Hayes 2009, Dudley et al. 2012).

Individual Black-backed Woodpeckers often colonize burned areas soon after fire when availability of key prey resources such as larvae of wood borers (Coleoptera: Cerambycidae and Buprestidae) and bark beetles (Coleoptera: Curculionidae) is highest. High woodpecker densities have been found in the 4- to 6-year period postfire (Saab et al. 2007, Nappi and Drapeau 2009, Saracco et al. 2011), with density often declining 6-10 years postfire (Siegel et al. 2016). Because habitat colonization is attributed largely to natal dispersal (Tremblay et al. 2015a, Seigel 
et al. 2016), and adults exhibit breeding-site fidelity (Tremblay et al. 2015a), reductions in Black-backed Woodpecker density over time may reflect the lifespan of individuals that colonize an area shortly postfire.

Relative to recently burned areas, Black-backed Woodpecker density and habitat associations outside recently burned areas have received less attention in western North America. In boreal forests of Alberta (Canada) and the northern Rocky Mountains (U.S.), Black-backed Woodpecker occupancy rates are substantially greater in burned than in unburned forest (Hoyt and Hannon 2002, Hutto 2008). However, in eastern boreal forests, Black-backed Woodpeckers commonly use unburned black spruce (Picea mariana) forests (Tremblay et al. 2009, 2010, 2015b), and in the Black Hills of South Dakota, they are found in ponderosa pine (Pinus ponderosa) (Mohren et al. 2014, 2016). Home ranges in unburned forest types include both open and forested areas (Tremblay et al. 2009), but foraging is generally restricted to older stands with recently dead snags (Tremblay et al. 2010). In eastern Canada, nesting Black-backed Woodpeckers prefer stands with high densities of recently decayed snags (Tremblay et al. 2015b), and use recently harvested stands for when suitable snags are available (Craig et al. 2019).

Until recently, use of green, unburned forests by Black-backed Woodpeckers in the western portion of their range was assumed to be a result of spillover from burned areas and was generally considered inconsequential to population viability (Odion and Hanson 2013). However, a survey across several National Forests in California (Fogg et al. 2014) reported higher densities of Blackbacked Woodpeckers in green forests than were previously found in burned forests of the northern Rocky Mountains, which highlighted the potential importance of this forest type in supporting regional populations. Despite large fires in western forests in recent years, most of the forest area within the range of Black-backed Woodpeckers in western North America has not burned recently enough to be considered optimal habitat (Hutto 2008, Odion and Hanson 2013, Hanson and Odion 2016).

If proposed genetic differences between populations in boreal forests, the Black Hills, and Oregon/California (Pierson et al. 2010) define subspecies, it may become even more important to understand how all forest types in a particular region support viability of regional Black-backed Woodpecker populations. Further, there is concern about the viability of the Oregon/ California population (Odion and Hanson 2013) due to potential negative effects of fire suppression and postfire salvage logging (Hanson and North 2008, Odion and Hanson 2013, Hanson and Odion 2016). Robust estimates of Black-backed Woodpecker occupancy of green forests is an important step in determining the extent to which these forests provide habitat for this species.

Thus, there is a need to assess whether green forests, that have not recently burned, provide habitat for Black-backed Woodpeckers, especially in the westernmost portion of their range. Toward that goal, we (1) estimated detection and occupancy probabilities of Black-backed Woodpeckers in green forests along the east slope of the southern Cascade Mountains, Oregon, and (2) evaluated associations between occupancy probability and green forest structural characteristics.

\section{METHODS}

\section{Study area}

Our study area included the Chemult, Chiloquin, and Klamath Ranger Districts of Fremont-Winema National Forest in the southern Cascade Mountains of Oregon, USA (Fig. 1). Elevation averaged $1575 \mathrm{~m}$ (range: $1300-2120 \mathrm{~m}$ ) and spanned a gradient of coniferous forest types that grow the on the volcanic soils of the southern Oregon Cascades and upper Klamath Basin. Dominant tree species in the study area include ponderosa pine, lodgepole pine (Pinus contorta), and white fir (Abies concolor). Precipitation during breeding seasons (April-July) varied from $71 \mathrm{~mm}$ (2014) to $84 \mathrm{~mm}$ (2015) (SNOTEL weather station, Sun Pass, Oregon, $1636 \mathrm{~m}$ elevation). Temperatures during that same period averaged $12^{\circ} \mathrm{C}$ in 2014 and $13^{\circ} \mathrm{C}$ in 2015 . Daily minimum/ maximum temperatures ranged from $-7^{\circ} \mathrm{C}$ to $33^{\circ} \mathrm{C}$, respectively. The historical fire regime likely included frequent, low-intensity burns (Agee 1994). At the time surveys were conducted, only two transects were within $10 \mathrm{~km}$ of a recently burned forest (i.e., wildfire occurring after the year 2000) (Fig. 1). Forest management in the Chemult, Chiloquin, and Klamath Ranger Districts of Fremont-Winema National Forest includes dry forest restoration to reduce fuel loads, improve wildlife habitat, and maintain existing late-successional and old-growth forests. Active management includes thinning to remove smaller diameter subdominant or understory trees $(17.8-53.3 \mathrm{~cm}$ diameter at breast height [dbh]) while promoting old or large ponderosa pine stands (Charnley et al. 2017).

Fig. 1. Study area and location of Black-backed Woodpecker (BBWO) survey transects, 2014-2015, southern Cascades, Oregon, USA (NF: National Forest).

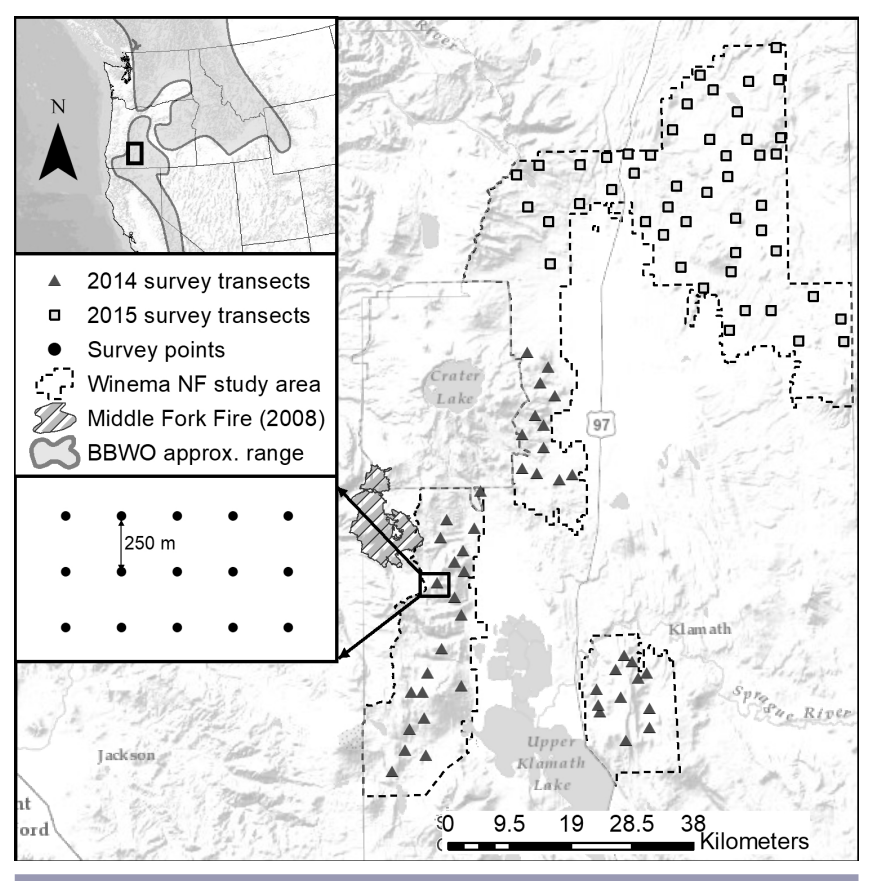




\section{Black-backed Woodpecker surveys}

We selected a stratified random sample of 90 transects to encompass the range of coniferous forest types present on National Forest lands within the study area. We used transects as our sampling unit to maintain sampling efficiency and to ensure that a significant portion of a Black-backed Woodpecker's potential home range was surveyed. We overlaid a 500 × $500 \mathrm{~m}$ grid on the study area and randomly selected grid cell centroids as the northwest corner of a survey transect. Each transect consisted of 15 survey points spaced $250 \mathrm{~m}$ apart and arranged in a $3 \times 5$ point grid, which resulted in approximately 141 ha sampled. It was not possible to define discrete forest stands based on common management history due to a long history of overlapping and unquantified forest management treatments (thinning, etc.) that have been implemented across broad spatial extents within the Fremont-Winema National Forest. Still, individual transects were sited to remain within relatively homogenous forest types that lacked variation in seral stage or species composition. Adjacent transects were no closer than 1500 $\mathrm{m}$ from one another and thus were considered spatially independent based on known home range sizes in green forests (Tremblay et al. 2009).

Substantial differences in detection probability for Black-backed Woodpeckers exist between point count and broadcast acoustical monitoring or playback-based surveys (up to four times as many detections using playback calls), possibly due to the species' relatively large home range size (Russell et al. 2009, Saracco et al. 2011) and generally cryptic behavior, except when responding to territory disputes. Thus, we implemented playback call surveys for Black-backed Woodpeckers following standard methodology (Saracco et al. 2011). Surveys were conducted mid-April through July, which spanned the potential breeding season in the region. Each transect was surveyed three times per year, with different transects surveyed each year. Surveys were limited to mornings when rain, fog, or wind did not interfere with sight or sound.

Surveys began within 10 minutes of local sunrise and were completed by noon. The survey protocol, developed by the Institute for Bird Populations, was 6 minutes long, and consisted of three increments of 30 -second broadcasts followed by 1.5 minutes of listening each. This protocol has become the standard for Black-backed Woodpecker monitoring in burned and unburned forests of the Sierra Nevada (Fogg et al. 2014, Siegel et al. 2014). Surveyors played recordings using a Wildlife Technologies model MA-15 caller at a standard volume ( $90 \mathrm{~dB}$ at $1 \mathrm{~m}$ ). The caller was placed on a stump or log above the ground when possible, positioned parallel to the ground topography, and turned approximately $120^{\circ}$ before each subsequent broadcast. To minimize disturbance to nesting birds, we discontinued playback at the survey point after a Black-backed Woodpecker was detected.

\section{Vegetation sampling}

We made detailed measurements of forest conditions around detection and nondetection locations to quantify habitat features presumed to be of greatest importance to Black-backed Woodpeckers in the region (Cahall and Hayes 2009, Fogg et al. 2014). We completed vegetation surveys at eight points on each survey transect: up to four points where Black-backed Woodpeckers were detected and the remainder at predetermined random points. We collected tree data on variable radius survey plots based on a basal area factor of 40 (Criterion RD 1000 electronic basal area factor scope/dendrometer). For each tree within the plot, surveyors recorded species, dbh $(\mathrm{cm})$, tree height (m), and tree defect (e.g., presence of mistletoe, cavity, broken top). Within a $16-\mathrm{m}$ radius plot, snags $\geq 3 \mathrm{~m}$ tall and $\mathrm{dbh} \geq 10 \mathrm{~cm}$ were recorded along with species, dbh, height, categorical decay class (Cline et al. 1980), and tree defect. Understory data were collected to assess whether shrubs may indicate prey availability, as has been demonstrated for other species (Martinuzzi et al. 2009). We measured shrub species and percent cover in $5 \%$ increments.

\section{Statistical analyses}

The transect $(n=90)$ was the unit of analysis for determining Black-backed Woodpecker occupancy and assessing relationships with associated forest structure covariates, the latter derived from averaging eight vegetation plots per transect. The study employed transect-scale analyses because individual survey points do not represent independent samples when using active playback calling methodology. Individual woodpeckers are known to follow playback calls from station to station (Hartwig et al. 2002). Our 15-point transects were designed to sample an area equivalent to a relatively small Black-backed Woodpecker home range (Tremblay et al. 2009). We considered the sampled area of the transect to represent a forest stand and serve as the unit of analysis.

We used a model developed by MacKenzie et al. (2002) to estimate probability of occupancy of a forest stand by any Black-backed Woodpecker. We conducted analyses in the package unmarked in R (R Development Core Team 2010, Fiske and Chandler 2011). Our expectation was that detection probability would peak during the sampling season (which closely followed the breeding season), so we included a quadratic ordinal date covariate in the detection portion of the model. Given the observational study design and our general interest in evaluating associations between abiotic and biotic covariates and occupancy, we fit individual models with only one covariate in the occupancy portion of the model (four models total). We investigated effects of snag basal area (Rota et al. 2014b), number of large snags (> $27 \mathrm{~cm} \mathrm{dbh}$ ) (Rota et al. 2014b), elevation (Fogg et al. 2014), and precipitation (Fogg et al. 2014), which have all been shown to influence Black-backed Woodpecker occupancy. We plotted the mean and standard deviation for several vegetation characteristics (shrub species richness, shrub cover, tree density, tree $\mathrm{dbh}$, snag basal area, and number of large snags) to make comparisons between unoccupied sites, single occupancy, and pair occupancy.

\section{RESULTS}

Across two years of sampling, we detected Black-backed Woodpeckers on $77 / 90(86 \%)$ transects. We detected single birds and pairs on $41(46 \%)$ and $36(40 \%)$ transects, respectively; we did not detect any Black-backed Woodpeckers on the remaining 13 $(14 \%)$ transects. We detected Black-backed Woodpeckers during $964 / 4050$ individual surveys (24\%). Most transects were in mixed conifer - true fir (Abies spp.)/pine (20;22\%), lodgepole pine (27; $30 \%)$, and ponderosa pine $(20 ; 22 \%)$ forest types; we surveyed only a small number of transects in true fir $(12 ; 13 \%)$ and Englemann spruce (Picea englemannii)/western hemlock (Tsuga heterophylla) $(4 ; 4 \%)$ forest types. 
Mean occupancy across all transects was 0.87 (95\% CI: $0.78-0.93$ ). We did not fit occupancy models for forest type due to a lack of variation in naïve occupancy for stands in mixed conifer (0.81), lodgepole pine (1.00), and ponderosa pine (0.90), or because of small sample sizes in true fir (0.50) and spruce/hemlock (1.00). We found little variation in occupancy by annual precipitation, large snag density, or snag basal area (Fig. 2). Black-backed Woodpecker occupancy was not clearly related to elevation, although a positive association existed across our relatively narrow elevation gradient (Fig. 2). We further explored forest structural characteristics based on whether naïve occupancy status of transects was unoccupied or occupied by singles or pairs. Transects with observed pair occupancy had fewer than half as many trees on average (1.93 \pm 1.21 trees per basal area factor 40 plot) when compared to transects without detections $(4.52 \pm 1.67$ trees per basal area factor 40 plot). There were approximately $24 \%$ fewer shrub species on transects with observed pair occupancy ( $4.22 \pm 0.89$ shrub species) when compared to transects without detections $(5.55 \pm 1.13 \mathrm{shrub}$ species). Transects with pair occupancy had an approximately $25 \%$ smaller average tree dbh $(34.65 \pm 12.94 \mathrm{~cm})$ when compared to transects without detections $(46.66 \pm 8.29 \mathrm{~cm})$. Finally, number of snags/hectare was not different among transects with observations of pairs or singles, and those lacking detections (Fig. 3).

Fig. 2. Association between occupancy $(95 \% \mathrm{CI})$ and four forest structure covariates for Black-backed Woodpeckers, 2014-2015, southern Cascades, Oregon, USA.

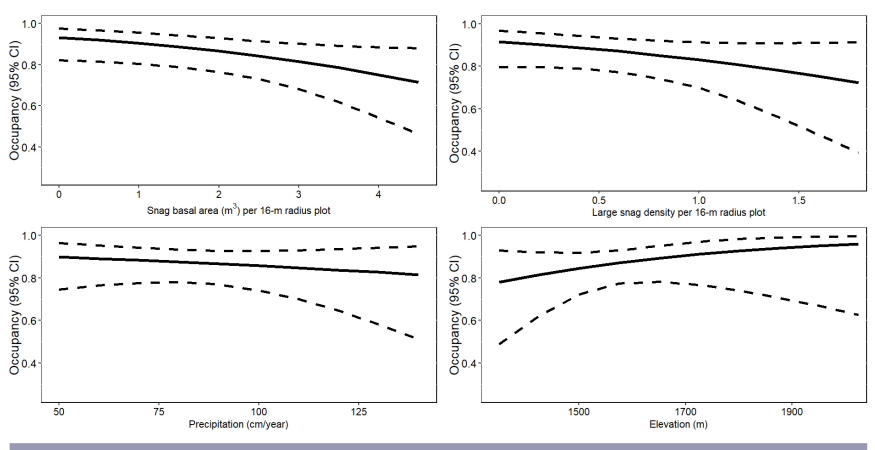

Fig. 3. Summary of habitat covariates for Black-backed Woodpeckers, 2014-2015, southern Cascades, Oregon, USA (dbh: diameter at breast height).
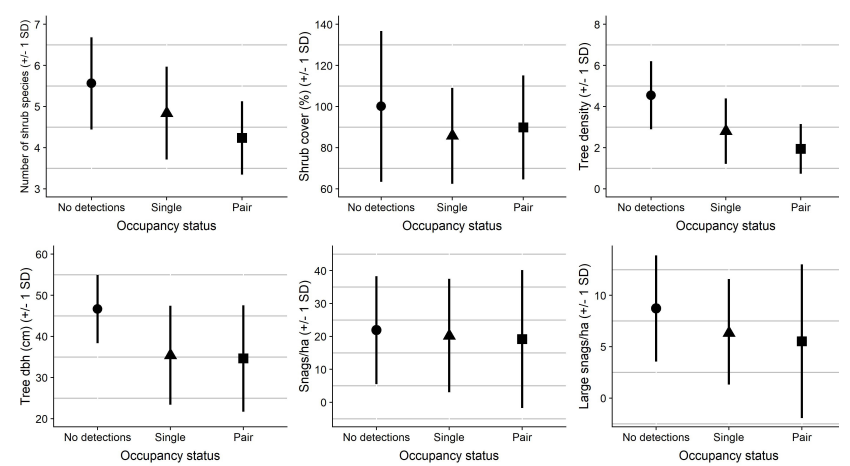

Detection probability varied during the survey season, with transect-level detection probability reaching a maximum of 0.79 (95\% CI: 0.70-0.85) in the middle of June (Fig. 4). However, we note that only $38 / 270(14 \%)$ of surveys were conducted before 1 June across both years. Therefore, uncertainty in detection probability may reflect small sample sizes rather than actual variation in Black-backed Woodpecker responses prior to 1 June. Juvenile Black-backed Woodpeckers and active nest cavities were noted incidentally during playback call surveys in the latter part of the survey period.

Fig. 4. Detection probability $(95 \% \mathrm{CI})$ as a function of date for Black-backed Woodpeckers using green forest types, 2014-2015, southern Cascades, Oregon, USA.

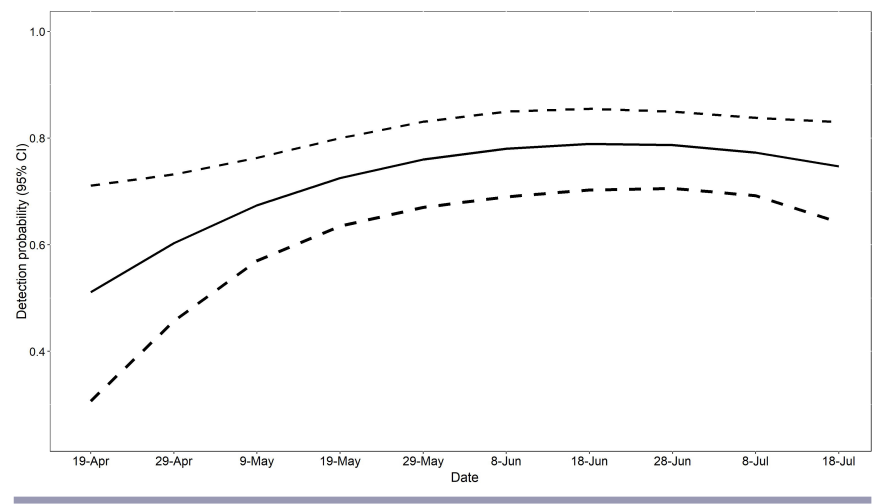

\section{DISCUSSION}

Our study adds to a small but growing body of literature that has documented Black-backed Woodpecker occupancy and nesting in green forests (Fogg et al. 2014, Tremblay et al. 2015a), despite the species' well-documented association with burned forests across its range (Hanson and North 2008, Hutto 2008, Cahall and Hayes 2009, Dudley et al. 2012). Mean transect-scale Black-backed Woodpecker occupancy was 0.87 in green forests that were composed primarily of mixed conifer, lodgepole pine, or ponderosa pine, but also less commonly included true fir and spruce/hemlock forests. The lack of substantial variation in occupancy by annual precipitation, large snag density, or snag basal area may be due in part to low variation in occupancy across transects. Our results demonstrate consistently high Black-backed Woodpecker occupancy in green forests along the east slope of the southern Cascade Mountains, Oregon, USA, and emphasize the need for more inclusive treatment of how different forest types contribute to population viability of this species in western North America.

Transect-level occupancy in this study was much higher than expected based on prior efforts. The mean occupancy estimate of 0.87 on 90 transects (141 ha of surveyed area each) suggests that Black-backed Woodpecker density is likely higher along the east slope of the southern Oregon Cascades than in the Sierra Nevada where Fogg et al. (2014) reported a density of 0.21 birds/100 ha in green forests. In that same geographic area, Saracco et al. (2011) found mean occupancy to be 0.097 and a detection probability of 0.772 in burned forests. Regional population estimates that 
consider Black-backed Woodpecker use of green forests may be substantially higher than would be expected from burned forests alone.

Despite comparable detection probabilities, it should be noted that some variation in occupancy estimates across studies is likely the result of different survey methods. Many prior assessments of Black-backed Woodpecker occupancy and habitat associations have used passive point count sampling (Haggard and Gaines 2001, Smucker et al. 2005) or a mix of point count and playback methodology (Saracco et al. 2011), often using passive surveys and playback surveys occurring in sequence as separate visits (Fogg et al. 2014). We applied playback call methodology (Saracco et al. 2011) on three separate visits spread across the breeding season (instead of sequential sampling) to estimate Black-backed Woodpecker occupancy at transect scales. Using transect-level data in the analysis addresses potential bias that might result from incorrectly associating occupancy with forest structural characteristics at an individual survey point when birds may have traveled in response to the playback call. However, we suggest that future studies consider study designs that use individual Black-backed Woodpecker territories as the unit of inference, as doing so will allow for the identification of forest structural characteristics in green forests associated with occupancy, and measures of fitness such as reproduction and survival. Since passive sampling during a point count visit has four times lower detection rates than playback calls (Russell et al. 2009, Saracco et al. 2011), and playback methodology maintains a potential bias in observations of occupied habitat, we propose using autonomous recording units as an alternative method for surveying territories more effectively.

Although our study did not examine colonization or persistence, we did find evidence of nesting and fledglings, which indicated that breeding occurred on a portion of the transects. In green forests, Fogg et al. (2014) found site colonization and local extinction probabilities to be low ( 0.05 and 0.19 , respectively), which indicated the relative stability of those home ranges. Even within burned forests, complex dynamics can influence postfire colonization and persistence (Stillman et al. 2019). Tingley et al. (2018) found colonization and persistence declined across and within burned areas with time since fire, and at a given fire site, colonization decreased with fire size and increased with fire severity and later ignition dates.

Black-backed Woodpecker associations with forest structural characteristics and abiotic factors have been well described in some regions (northern Rocky Mountains [Smucker et al. 2005, Dudley and Saab 2007, Dudley et al. 2012], Black Hills of South Dakota [Bonnot et al. 2008, 2009, Rota et al. 2014b, 2015], eastern boreal forests of Quebec [Huot and Ibarzabal 2006, Tremblay et al. 2009, 2010, 2015a, Nappi et al. 2010], mixed conifer forests in California [Saracco et al. 2011, Seavy et al. 2012, Fogg et al. 2014]). Tremblay et al. (2009) found Black-backed Woodpeckers successfully bred in unburned forest with $35 \mathrm{~m}^{3} /$ ha of dead wood, of which $42 \%\left(15 \mathrm{~m}^{3} / \mathrm{ha}\right)$ was represented by dead wood in the early decay stage. In green forests of the Sierra Nevada, California, Black-backed Woodpecker occupancy was better explained by physiographic variables rather than forest structure, where the strongest relationships were with elevation, latitude, and forest type (lodgepole pine), but to a lesser extent, with large trees and high snag density (Fogg et al. 2014). Black-backed Woodpecker occupancy was consistently high across the relatively modest elevational gradient of our study area, which created a challenge for linking occupancy to forest structure or abiotic attributes. Although an analysis undertaken for individual survey points may have provided greater variation in occupancy status when compared to transect-scale results, relationships between occupancy forest structure would likely be spurious because individuals were drawn toward the playback call from significant distances. Black-backed Woodpeckers were commonly seen following the observer between multiple points (more than two) within a transect. Responses to playback calls were often first heard $>200 \mathrm{~m}$ from the observer but were noted to be moving closer, eventually (within the same survey period) within $25 \mathrm{~m}$ of the survey point.

Availability of food resources has been directly linked to population regulation (Villard and Benninger 1993, Murphy and Lehnhausen 1998, Rota et al. 2014a) and is undoubtedly an important component of Black-backed Woodpecker occupancy patterns in both burned and unburned forests. High-severity fires create relatively high initial prey availability and are reported to be particularly important for Black-backed Woodpeckers (Smucker et al. 2005, Hanson and North 2008, Hutto 2008), whereas other disturbance types such as widespread beetle infestations do not provide the same magnitude of resource (Bonnot et al. 2008, 2009, Tingley et al. 2020). Tremblay et al. (2016) found that both male and female Black-backed woodpeckers had higher food delivery rates and spent less time at the nest per delivery in burned forests compared to green forests, which suggests that greater effort may be needed to raise young in green forests. Forests in our study area did not have recent fire or beetle damage, and we assumed they would have fewer prey resources, which would lead to lower occupancy. Lower tree densities on transects where pairs were observed (Fig. 3) is in contrast to prior findings that higher tree densities were indicative of greater Black-backed Woodpecker occupancy in green forests (Hoyt and Hannon 2002) and postburn (Hutto 2008). This may indicate the importance of biophysical factors (e.g., volcanic soils, areas of early frost) that may be regulating tree vigor and health, and ultimately forage availability. A previous study further east on the Fremont-Winema National Forest did not detect any Black-backed Woodpecker nests in unburned forests, compared to 21 nests in nearby burned areas (Russell et al. 2009). In an experimental study in the same region, Kroll et al. $(2010,2012)$ found Black-backed Woodpeckers breeding successfully in forests with bark beetle infestations and infested forests that were salvage logged. A pilot demography study implemented in 2016 in our study area found active nests on $23 \%$ of previously surveyed transects, which provided evidence that Black-backed Woodpeckers hold territories and nest in green forests (Halstead and Stephens 2015).

Further study of key vital rates that underlie populations and are linked to recruitment (e.g., nest survival, postfledgling survival) will be necessary to determine the full extent to which green forests support Black-backed Woodpeckers on a regional basis. In eastern Canadian boreal forest, it has been reported that unburned habitat may provide Black-backed Woodpeckers with more temporally stable resources, which has potential benefit to long-term persistence of the species (Tremblay et al. 2015a). If 
Avian Conservation and Ecology 16(1): 4 http://www.ace-eco.org/vol16/iss1/art4/

the same line of reasoning applies to forests of western North America, green forests may be key to sustaining Black-backed Woodpecker populations on landscape and regional scales, particularly with the variable temporal and spatial pattern of large-scale, stand-replacing fires.

\section{CONCLUSION}

Our results confirm recent findings from northern California (Fogg et al. 2014), eastern Canada (Tremblay et al. 2009, 2015a), the Black Hills of South Dakota (Mohren et al. 2014, 2016), and other studies in southern Oregon (Kroll et al. 2012) where Blackbacked Woodpeckers were found using green forests. Collectively, these studies establish that this species exhibits different habitat associations across its range and, at least in some areas, uses green forests extensively. A critical next step is to quantify vital rates in green and nearby unburned forests to understand the relative contribution of these two forest types in supporting populations, and to document the extent to which individuals breeding in these forest types are connected via the movement of individuals, particularly through natal dispersal.

Responses to this article can be read online at: https://www.ace-eco.org/issues/responses.php/1725

\begin{abstract}
Acknowledgments:
We thank Chris Adlam, Jaime Blankenship, Patrick Flaherty, Eva Leach, Kendall Norcott, Andrew Orahoske, Graeme Riggins, and Andrew Wiegardt for field support. Additional logistic support was provided by Kelley Breen, Katie Knox, Frank Lospalluto, Suzanne Rock, Sarah Rockwell, and Heidi Timms. We appreciate the support and guidance from John Alexander for Klamath Bird Observatory's scientific studies. Funding was provided by the National Council for Air and Stream Improvement and the Bureau of Land Management. Jim Rivers provided thoughtful review of the draft manuscript.
\end{abstract}

\section{LITERATURE CITED}

Agee, J. K. 1994. Fire and weather disturbances in terrestrial ecosystems of the eastern Cascades. U.S. Forest Service General Technical Report PNW-GTR-320, Portland, Oregon, USA. https://doi.org/10.2737/PNW-GTR-320

Aubrey, K. B., and C. M. Raley. 2002. The Pileated Woodpecker as a keystone habitat modifier in the Pacific Northwest. U.S. Forest Service General Technical Report PSW-GTR-181. Olympia, Washington, USA.

Bonnot, T. W., J. J. Millspaugh, and M. A. Rumble. 2009. Multiscale nest-site selection by Black-backed Woodpeckers in outbreaks of mountain pine beetles. Forest Ecology and Management 259:220-228. https://doi.org/10.1016/j.foreco.2009.10.021

Bonnot, T. W., M. A. Rumble, and J. J. Millspaugh. 2008. Nest success of Black-backed Woodpeckers in forests with mountain pine beetle outbreaks in the Black Hills, South Dakota. Condor 110:450-457. https://doi.org/10.1525/cond.2008.8460

Cahall, R. E., and J. P. Hayes. 2009. Influences of postfire salvage logging on forest birds in the eastern Cascades, Oregon, USA.
Forest Ecology and Management 257:1119-1128. https://doi. org/10.1016/j.foreco.2008.11.019

Charnley, S., T. A. Spies, A. M. G. Barros, E. M. White, and K. A. Olsen. 2017. Diversity in forest management to reduce wildfire losses: implications for resilience. Ecology and Society 22:22. https://doi.org/10.5751/ES-08753-220122

Cline, S. P., A. B. Berg, and H. M. Wight. 1980. Snag characteristics and dynamics in Douglas-fir forests, western Oregon. Journal of Wildlife Management 44:773-786. https://doi. org/10.2307/3808305

Craig, C., M. J. Mazerolle, P. D. Taylor, J. A. Tremblay, and M.A. Villard. 2019. Predictors of habitat use and nesting success for two sympatric species of boreal woodpeckers in an unburned, managed forest landscape. Forest Ecology and Management 438:134-141. https://doi.org/10.1016/j.foreco.2019.02.016

Drever, M. C., K. E. H. Aitken, A. R. Norris, and K. Martin. 2008. Woodpeckers as reliable indicators of bird richness, forest health and harvest. Biological Conservation 141:624-634. https:// doi.org/10.1016/j.biocon.2007.12.004

Dudley, J. G., and V. A. Saab. 2007. Home range size of Blackbacked Woodpeckers in burned forests of southwestern Idaho. Western North American Naturalist 67:593-600. https://doi. org/10.3398/1527-0904(2007)67[593:HRSOBW]2.0.CO;2

Dudley, J. G., V. A. Saab, and J. P. Hollenbeck. 2012. Foraginghabitat selection of Black-backed Woodpeckers in forest burns of southwestern Idaho. Condor 114:348-357. https://doi.org/10.1525/ cond.2012.110020

Fiske, I., and R. Chandler. 2011. Unmarked: an R package for fitting hierarchical models of wildlife occurrence and abundance. Journal of Statistical Software 43:1-23. https://doi.org/10.18637/ jss.v043.i10

Fogg, A. M., L. J. Roberts, and R. D. Burnett. 2014. Occurrence patterns of Black-backed Woodpeckers in green forest of the Sierra Nevada mountains, California, USA. Avian Conservation and Ecology 9(2):3. https://doi.org/10.5751/ACE-00671-090203

Haggard, M., and W. L. Gaines. 2001. Effects of standreplacement fire and salvage logging on a cavity-nesting bird community in eastern Cascades, Washington. Northwest Science 75:387-396.

Halstead, K. E., and J. L. Stephens. 2015. Black-backed Woodpecker nest search surveys in the Upper Klamath Basin, Oregon: Klamath Bird Observatory 2015 summary report. Klamath Bird Observatory, Ashland, Oregon, USA.

Hanson, C. T., and M. P. North. 2008. Postfire woodpecker foraging in salvage-logged and unlogged forests of the Sierra Nevada. Condor 110:777-782. https://doi.org/10.1525/cond.2008.8611

Hanson, C. T., and D. C. Odion. 2016. Historical forest conditions within the range of the Pacific fisher and Spotted Owl in the central and southern Sierra Nevada, California, USA. Natural Areas Journal 36:8-19. https://doi.org/10.3375/043.036.0106

Hartwig, C. L., D. S. Eastman, and A. S. Harestad. 2002. Forest age and relative abundance of Pileated Woodpeckers on southeastern Vancouver Island. Pages 247-256 in W. F. 
Laudenslayer, Jr., P. J. Shea, B. E. Valentine, E. Bradley, C. Weatherspoon, L. Phillip, and T. E. Lisle, technical coordinators. Proceedings of the Symposium on the Ecology and Management of Dead Wood in Western Forests (Reno, Nevada, 2-4 November 1999). U.S. Forest Service General Technical Report PSWGTR-181. Albany, California, USA.

Hoyt, J. S., and S. J. Hannon. 2002. Habitat associations of Blackbacked and Three-toed Woodpeckers in the boreal forest of Alberta. Canadian Journal of Forest Research 32:1881-1888. https://doi.org/10.1139/x02-109

Huot, M., and J. Ibarzabal. 2006. A comparison of the age-class structure of Black-backed Woodpeckers found in recently burned and unburned boreal coniferous forests in eastern Canada. Annales Zoologici Fennici 43:131-136.

Hutto, R. L. 2008. The ecological importance of severe wildfires: some like it hot. Ecological Applications 18:1827-1834. https://doi. org/10.1890/08-0895.1

Kroll, A. J., E. B. Arnett, and B. Altman. 2010. Effects of salvage logging on avian nest survival in beetle-killed forests. Forest Ecology and Management 260:1599-1606. https://doi.org/10.1016/ j.foreco.2010.08.009

Kroll, A. J., J. Giovanini, J. E. Jones, E. B. Arnett, and B. Altman. 2012. Effects of salvage logging of beetle-killed forests on avian species and foraging guild abundance. Journal of Wildlife Management 76:1188-1196. https://doi.org/10.1002/jwmg.353

MacKenzie, D. I., J. D. Nichols, G. B. Lachman, S. Droege, J. A. Royle, and C. A. Langtimm. 2002. Estimating site occupancy rates when detection probabilities are less than one. Ecology 83:2248-2255. https://doi.org/10.1890/0012-9658(2002)083[2248: ESORWD]2.0.CO;2

Martin, K., K. E. H. Aitken, and K. L. Wiebe. 2004. Nest sites and nest webs for cavity-nesting communities in interior British Columbia, Canada: nest characteristics and niche partitioning. Condor 106:5-19. https://doi.org/10.1093/condor/106.1.5

Martinuzzi, S., L. A. Vierling, W. A. Gould, M. J. Falkowski, J. S. Evans, A. T. Hudak, and K. T. Vierling. 2009. Mapping snags and understory shrubs for a LiDAR-based assessment of wildlife habitat suitability. Remote Sensing of Environment 113:2533-2546. https://doi.org/10.1016/j.rse.2009.07.002

Mikusinski, G., M. Gromadzki, and P. Chylarecki. 2001. Woodpecker as indicators of forest bird diversity. Conservation Biology 15:208-217.

Mohren, S. R., M. A. Rumble, and S. H. Anderson. 2014. Density and abundance of Black-backed Woodpeckers in a ponderosa pine ecosystem. Prairie Naturalist 46:62-69.

Mohren, S. R., M. A. Rumble, C. P. Lehman, and S. H. Anderson. 2016. Resource selection by Black-backed Woodpeckers (Picoides arcticus) and American Three-toed Woodpeckers (P. dorsalis) in South Dakota and Wyoming. Prairie Naturalist 47:21-29.

Murphy, E. C., and W. A. Lehnhausen. 1998. Density and foraging ecology of woodpeckers following a stand-replacement fire. Journal of Wildlife Management 62:1359-1372. https://doi. org/10.2307/3802002
Nappi, A., and P. Drapeau. 2009. Reproductive success of the Black-backed Woodpecker (Picoides arcticus) in burned boreal forests: Are burns source habitats? Biological Conservation 142:1381-1391. https://doi.org/10.1016/j.biocon.2009.01.022

Nappi, A., P. Drapeau, M. Saint-Germain, and V. A. Angers. 2010. Effect of fire severity on long-term occupancy of burned boreal conifer forests by saproxylic insects and wood-foraging birds. International Journal of Wildland Fire 19:500-511. https:// doi.org/10.1071/WF08109

Odion, D. C., and C. T. Hanson. 2013. Projecting impacts of fire management on a biodiversity indicator in the Sierra Nevada and Cascades, USA: the Black-backed Woodpecker. Open Forest Science Journal 6:14-23. https://doi.org/10.2174/1874398620130508001

Pierson, J. C., F. W. Allendorf, V. Saab, P. Drapeau, and M. K. Schwartz. 2010. Do male and female Black-backed Woodpeckers respond differently to gaps in habitat? Evolutionary Applications 3:263-278. https://doi.org/10.1111/j.1752-4571.2009.00111.x

R Development Core Team. 2010. R: a language and environment for statistical computing. R Foundation for Statistical Computing, Vienna, Austria.

Remm, J., and A. Lõhmus. 2011. Tree cavities in forests - the broad distribution pattern of a keystone structure for biodiversity. Forest Ecology and Management 262:579-585. https://doi.org/10.1016/j. foreco.2011.04.028

Rota, C. T., J. J. Millspaugh, M. A. Rumble, C. P. Lehman, and D. C. Kesler. 2014a. The role of wildfire, prescribed fire, and mountain pine beetle infestations on the population dynamics of Black-backed Woodpeckers in the Black Hills, South Dakota. PLoS ONE 9(8):e106390. https://doi.org/10.1371/journal. pone.0094700

Rota, C. T., M. A. Rumble, C. P. Lehman, D. C. Kesler, and J. J. Millspaugh. 2015. Apparent foraging success reflects habitat quality in an irruptive species, the Black-backed Woodpecker. Condor 117:178-191. https://doi.org/10.1650/CONDOR-14-112.1

Rota, C. T., M. A. Rumble, J. J. Millspaugh, C. P. Lehman, and D. C. Kesler. 2014b. Space-use and habitat associations of Blackbacked Woodpeckers (Picoides arcticus) occupying recently disturbed forests in the Black Hills, South Dakota. Forest Ecology and Management 313:161-168. https://doi.org/10.1016/j.foreco.2013.10.048

Russell, R. E., V. A. Saab, J. J. Rotella, and J. G. Dudley. 2009. Detection probabilities of woodpecker nests in mixed conifer forests in Oregon. Wilson Journal of Ornithology 121:82-88. https://doi.org/10.1676/08-026.1

Saab, V. A., R. E. Russell, and J. G. Dudley. 2007. Nest densities of cavity-nesting birds in relation to postfire salvage logging and time since wildfire. Condor 109:97-108. https://doi.org/10.1093/ condor/109.1.97

Saracco, J. F., R. B. Siegel, and R. L. Wilkerson. 2011. Occupancy modeling of Black-backed Woodpeckers on burned Sierra Nevada forests. Ecosphere 2:1-17. https://doi.org/10.1890/ ES10-00132.1 
Seavy, N. E., R. D. Burnett, and P. J. Taille. 2012. Black-backed Woodpecker nest-tree preference in burned forests of the Sierra Nevada, California. Wildlife Society Bulletin 36:722-728. https:// doi.org/10.1002/wsb.210

Siegel, R. B., M. W. Tingley, and R. L. Wilkerson. 2014. Blackbacked Woodpecker management indicator species surveys on Sierra Nevada National Forests: 2013 annual report. Institute for Bird Populations, Point Reyes Station, California, USA.

Siegel, R. B., M. W. Tingley, R. L. Wilkerson, C. A. Howell, M. Johnson, and P. Pyle. 2016. Age structure of Black-backed Woodpecker populations in burned forests. Auk 133:69-78. https://doi.org/10.1642/AUK-15-137.1

Smucker, K. M., R. L. Hutto, and B. M. Steele. 2005. Changes in bird abundance after wildfire: importance of fire severity and time since fire. Ecological Applications 15:1535-1549. https://doi. org/10.1890/04-1353

Stillman, A. N., R. B. Siegel, R. L. Wilkerson, M. Johnson, and M. W. Tingley. 2019. Age-dependent habitat relationships of a burned forest specialist emphasise the role of pyrodiversity in fire management. Journal of Applied Ecology 56:880-890. https://doi. org/10.1111/1365-2664.13328

Tingley, M. W., A. N. Stillman, R. L. Wilkerson, C. A. Howell, S. C. Sawyer, and R. B. Siegel. 2018. Cross-scale occupancy dynamics of a postfire specialist in response to variation across a fire regime. Journal of Animal Ecology 87:1484-1496. https://doi. org/10.1111/1365-2656.12851

Tingley, M. W., A. W. Stillman, R. L. Wilkerson, S. C. Sawyer, and R. B. Siegel. 2020. Black-backed Woodpecker occupancy in burned and beetle-killed forests: disturbance agent matters. Forest Ecology and Management 455:117694. https://doi.org/10.1016/j. foreco.2019.117694

Tremblay, J. A., J. Ibarzabal, C. Dussault, and J.-P. L. Savard. 2009. Habitat requirements of breeding Black-backed Woodpeckers (Picoides arcticus) in managed, unburned boreal forest. Avian Conservation and Ecology 4(1):2. https://doi. org/10.5751/ACE-00297-040102

Tremblay, J. A., J. Ibarzabal, M.-C. Saulnier, and S. Wilson. 2016. Parental care by Black-backed Woodpeckers in burned and unburned habitats of eastern Canada. Ornis Hungarica 24:69-80. https://doi.org/10.1515/orhu-2016-0004

Tremblay, J. A., J. Ibarzabal, and J.-P. L. Savard. 2010. Foraging ecology of Black-backed Woodpeckers (Picoides arcticus) in unburned eastern boreal forest stands. Canadian Journal of Forest Research 40:991-999. https://doi.org/10.1139/X10-044

Tremblay, J. A., J. Ibarzabal, and J. P. Savard. 2015a. Contribution of unburned boreal forests to the population of Black-backed
Woodpecker in eastern Canada. Écoscience 22:145-155. https:// doi.org/10.1080/11956860.2016.1169386

Tremblay, J. A., J. Ibarzabal, and J. P. Savard. 2015b. Structural retention requirements for a key ecosystem engineer in coniferdominated stands of a boreal managed landscape in eastern Canada. Forest Ecology and Management 357:220-227. https:// doi.org/10.1016/j.foreco.2015.08.024

Virkkala, R. 2006. Why study woodpeckers? The significance of woodpeckers in forest ecosystems. Annales Zoologici Fennici 43:82-85.

Villard, P., and C. W. Benninger. 1993. Foraging behavior of male Black-backed and Hairy Woodpeckers in a forest burn. Journal of Field Ornithology 64:71-76.
Editor-in-Chief: Keith A.Hobson Subject Editor: Steven L.Van Wilgenburg

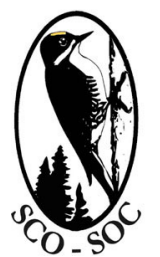

Sponsored by the Society of Canadian Ornithologists and Birds Canada

Parrainée par la Société des ornithologistes du Canada et Oiseaux Canada

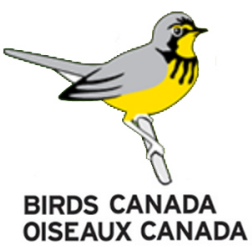

